\title{
FAKTOR-FAKTOR YANG BERHUBUNGAN DENGAN PERILAKU REMAJA JALANAN TERHADAP KESEHATAN REPRODUKSI DI YAYASAN PEMBINA ASUHAN BUNDA (YPAB) KOTA BATAM
}

\author{
Ulpawati $^{1),}$ Susanti ${ }^{2)}$ \\ 1) Program Studi Psikologi, Fakultas Kedokteran, Universitas Batam \\ ulpa.wati19@gmail.com \\ 2) Program Studi Diploma Kebidanan, Fakultas Kedokteran,Universitas Batam \\ susanti.1187@gmail.com
}

\begin{abstract}
ABSTRAK
Masa remaja merupakan masa peralihan antara masa anak-anak dan masa dewasa, dimulai pada saat kematangan seksual yaitu antara usia 10-12 tahun sampai 20 tahun, menjelang dewasa muda, anak jalanan merupakan anak yang melewatkan atau memanfaatkan sebagian besar waktunya untuk melakukan kegiatan sehari-hari dijalanan termasuk dilingkungan pasar, pertokoan dan pusat-pusat keramaian lainnya (Kementerian Sosial, 2016).

Tujuan penelitian untuk mengetahui faktor-faktor yang berhubungan dengan perilaku remaja jalanan terhadap kesehatan reproduksi di Yayasan Pembina Asuhan Bunda (YPAB) Kota Batam tahun 2019. Rancangan penelitian yang digunakan dalam penelitian ini adalah menggunakan survei analitik dengan menggunakan pendekatan cross sectional. Penelitian ini dilakukan pada bulan Mei sampai September 2019 di YPAB tahun 2019. Populasi dalam penelitian ini adalah 101 responden dengan jumlah sampel 101 responden, menggunakan teknik purposive sampling. Pengumpulan data dengan menggunakan instrumen kuisioner dan diisi oleh responden. Data dalam bentuk tabel dan tekstual analis mengunakan Chi-square.

Hasil uji statistik diperoleh 28 responden $(56,6 \%)$ berpengetahuan kurang, sikap negatif sebanyak 27 orang $(54,0 \%)$, pengaruh teman sebaya sebanyak 34 orang ( $68,0 \%)$ dan pengaruh akses media sosial sebanyak 31 orang $(62,0 \%)$. Ada hubungan yang signifikan antara pengetahuan, sikap teman sebaya dan akses media sosial dengan perilaku remaja jalanan terhadap kesehatan reproduksi di YPAB Kota Batam tahun 2019.
\end{abstract}

Kata kunci : pengetahuan, sikap, teman sebaya, akses media sosial

\begin{abstract}
Adolescence is a transitional period between childhood and adulthood, starting at sexual maturity, namely between the ages of 10-12 years to 20 years, before young adulthood, street children are children who spend or use most of their time to carry out daily activities. the day on the road includes market environments, shops and other busy centers (Ministry of Social Affairs, 2016).

The purpose of the investigation is for factors related to the behavior of street teenagers on health at the Batam City Bunda Asuhan Development Foundation (YPAB) in 2019.

The research design used in this study was a survey analytic using a cross sectional approach. This research was conducted from May to September 2019 at YPAB 2019. The population in this study were 101 respondents with a sample size of 101 respondents, using purposive sampling technique. Collecting data using a questionnaire instrument and filled out by respondents. Data in tabular form and textual analysis using Chi-square.

The results of statistical tests showed that 28 respondents (56.6\%) had less knowledge, 27 people (54.0\%) had negative attitudes, 34 people (68.0\%) had the influence of peers and 31 people (62,0\%). There is a significant relationship between knowledge, peer attitudes and access to social media with the behavior of street teenagers on association health at YPAB Batam City in 2019.
\end{abstract}

Keywords: Knowledge, attitudes, peers, access to social media 


\section{PENDAHULUAN}

Direktorat Jenderal Rehabilitasi Sosial mengidentifikasi masih ada 16.290 anak jalanan di seluruh Indonesia. Jumlah ini lebih sedikit bila dibandingkan dengan kondisi pada tahun 2006. Terjadi penurunan dari tahun 2006 sebanyak 232.894 anak, menjadi 16.290 anak tahun ini Data Anak Jalanan Agustus 2017 lalu memperlihatkan masih ada 16.290 anak jalanan yang tersebar di 21 provinsi. Untuk provinsi di luar Pulau Jawa, tercatat yang tertinggi di Provinsi Sumatera Utara dengan populasi 1.000 anak, diikuti Sumatera Barat sebanyak 822 anak, Sumatra Selatan sebanyak 652 anak, serta Kepulauan Riau sebanyak 455 anak (Suharto, 2018).

Menurut Kementerian Sosial (2015), banyak anak yang dibiarkan tanpa pengasuhan dan perlindungan yang memadai dan terpaksa menjadi anak jalanan. Anak jalanan terpapar pada masalah kesehatan, eksploitasi dan kekerasan, putus sekolah dan terlibat dalam aksi kejahatan. Hasil survei yang telah dilakukan oleh Komisi Perlindungan Anak Indonesia (KPAI) mengenai jumlah anak jalanan yang didata dari 2,9 juta anak terlantar, terdapat 34.400 anak jalanan (KPAI, 2016 dalam Ningsih 2016).

Kelompok umur remaja (usia 14-18 tahun) merupakan bagian terbesar dari kelompok anak jalanan. Anak jalanan menghabiskan sebagian besar waktu di jalanan sehingga meningkatkan kerentanan mereka terhadap gangguan kesehatan. Anak jalanan secara psikologi memiliki konsep diri negatif, tidak atau kurang percaya diri, mudah tersinggung, ketergantungan pada orang lain dan emosi yang tidak stabil. Kondisi ini menyebabkan mereka mudah terpengaruh orang lain dan 2 cenderung berperilaku antisosial seperti bekelahi, mencuri, merampas, menggunakan dan menjalankan bisnis narkotika, dan perilaku seks bebas. Mereka juga dapat mengalami eksploitasi fisik dan seksual terutama oleh orang dewasa hingga kehilangan nyawa, sehingga timbul masalah kesehatan reproduksi seperti infeksi menular seksual (KemenKes, 2014 dalam Ningsih 2016).

Masalah kesehatan reproduksi ketika melakukan seks bebas pada anak jalanan yang sering mereka lakukan tidak terlepas dari keadaan yang membuat anak jalanan itu harus bergantung kepada kehidupan anak jalanan dan dipengaruhi oleh rasa keingintahuan terhadap seks serta adanya pengaruh dari teman sekitar maupun pergaulan (Purba, 2012 dalam Ningsih 2016).

Berbagai akibat muncul disebabkan oleh perilaku seksual, antara lain KTD (Kehamilan Tidak Diinginkan), terkena PMS (Penyakit Menular Seksual), dan HIV (Human Immunodeficiency Virus) (Sunanti, 2001). Tingginya angka infeksi HIV pada anak jalanan dilatarbelakangi oleh perilaku berisiko terinfeksi HIV. Penelitian di Jakarta tahun 
2000 menyebutkan sebanyak 22,3\% anak jalanan sudah berhubungan seksual.

Hasil Survei Dasar Kesehatan Indonesia tahun 2012 menunjukkan bahwa pengetahuan remaja tentang kesehatan reproduksi belum memadai yang dapat dilihat dengan hanya $35,3 \%$ remaja perempuan dan $31,2 \%$ remaja laki-laki mengetahui perempuan dapat hamil dengan satu kali berhubungan seksual. Tingkat pengetahuan remaja laki-laki berupa pemahaman mengenai gejala infeksi menular seksual pada pria $16,4 \%$ dan pada perempuan $6,1 \%$, sedangkan tingkat pengetahuan remaja perempuan berupa pemahaman mengenai gejala infeksi menular seksual yang terjadi pada pria $15,8 \%$ dan pada perempuan $15,3 \%$ (Kemenkes RI, 2015 dalam Ningsih 2016).

Perilaku remaja jalanan terhadap kesehatan reproduksi cukup penting, sehingga remaja jalanan yang jumlahnya cenderung banyak dapat memahami dan menjaga dengan baik kesehatan reproduksinya dan masalah kesehatan reproduksi di Indonesia khususnya di kota Batam dapat berkurang.

Berdasarkan uraian latar belakang di atas, penulis merasa tertarik untuk melakukan penelitian dengan judul "Faktor-faktor yang Berhubungan dengan Perilaku Kesehatan Reproduksi di YPAB Kota Batam Tahun 2019”.

\section{METODE}

Penelitian adalah menggunakan survei analitik dengan menggunakan pendekatan Cross Sectional. Penelitian dilakukan pada bulan Mei sampai Agustus 2019 di Yayasan Pembina Asuhan Bunda Kota Batam Tahun 2019. Populasi dalam penelitian ini adalah 101 responden dengan jumlah sampel sebanyak 50 responden, menggunakan instrument kuesioner di isi oleh responden. Data dalam bentuk tabel dan tekstual Analisis Menggunakan Chisquare.

\section{HASIL DAN PEMBAHASAN \\ a. Hasil}

\section{Tabel 1 Distribusi frekuensi karakteristik} remaja jalanan di YPAB Batam

\begin{tabular}{lcc}
\hline Karakteristik & Frekuensi & \% \\
\hline 1. Pengetahuan & 22 & 44 \\
Baik & 28 & 56 \\
Kurang & $\mathbf{5 0}$ & $\mathbf{1 0 0}$ \\
Total & 23 & 46 \\
\hline 2. Sikap & 27 & 54 \\
\hline Positif & $\mathbf{5 0}$ & $\mathbf{1 0 0}$ \\
Negatif & \\
Total & 16 & 32 \\
\hline 3. Pengaruh Teman Sebaya & & 68 \\
\hline Pengaruh Baik & 34 & $\mathbf{1 0 0}$ \\
Pengaruh Buruk & $\mathbf{5 0}$ & \\
Total & & 38 \\
\hline 4. Akses Media Informasi & 19 & 62 \\
\hline Pernah & 31 & \\
Tidak Pernah & $\mathbf{5 0}$ & $\mathbf{1 0 0}$ \\
Total & 15 & 30 \\
\hline \multicolumn{1}{c}{ 5. Perilaku Kesehatan Reproduksi } \\
\hline Berperilaku \\
Tidak Berperilaku \\
Total & 35 & 70 \\
\hline & $\mathbf{5 0}$ & $\mathbf{1 0 0}$ \\
\hline
\end{tabular}

Berdasarkan tabel 1 dapat diketahui dari 50 responden, sebagian besar 28 responden (56\%) memiliki Pengetahuan kurang tentang kesehatan reproduksi, 27 responden (54\%) memiliki sikap yang negatif, 34 responden Jurnal Penelitian Kesehatan STIKes Dharma Husada Bandung 
(68\%) memiliki pengaruh teman sebaya yang buruk, 31 responden $(62 \%)$ tidak pernah mendapat informasi, serta sebanyak 35 orang
(70,0\%) yang tidak berperilaku kesehatan reproduksi.

Tabel 2 Hubungan Pengetahuan dengan Perilaku Kesehatan Reproduksi di YPAB Batam

\begin{tabular}{lccccccc}
\hline \multirow{3}{*}{ Pengetahuan } & \multicolumn{5}{c}{ Perilaku Kesehatan Reproduksi } & \multirow{2}{*}{ P Value } \\
\cline { 2 - 7 } & \multicolumn{1}{c}{ Tidak Berperilaku } & \multicolumn{2}{c}{ Berperilaku } & \multicolumn{2}{c}{ Total } & \\
\cline { 2 - 7 } & $\mathrm{F}$ & $\%$ & $\mathrm{~F}$ & $\%$ & $\mathrm{~F}$ & $\%$ & \\
\hline 1. Baik & 9 & 40,9 & 13 & 59,1 & 22 & 56,0 & \multirow{2}{*}{0,000} \\
\hline 2. Kurang & 26 & 92,9 & 2 & 7,1 & 28 & 44,0 & \\
\hline Total & 35 & 70,0 & 15 & 30,0 & 50 & 100 & \\
\hline
\end{tabular}

Berdasarkan tabel 2 diketahui (70\%) yang responden yang memiliki pengetahuan yang tidak berperilaku kesehatan reproduksi adalah kurang yaitu sebanyak 26 responden $(92,9 \%)$.

Tabel 3 Hubungan Sikap dengan Perilaku Kesehatan Reproduksi di YPAB Batam

\begin{tabular}{lccccccc}
\hline \multirow{3}{*}{ Sikap } & \multicolumn{9}{c}{ Perilaku Kesehatan } & \multirow{2}{*}{ P Value } \\
\cline { 2 - 7 } & \multicolumn{2}{c}{ Tidak Berperilaku } & \multicolumn{2}{c}{ Berperilaku } & \multicolumn{2}{c}{ Total } & \\
\cline { 2 - 7 } & $\mathrm{F}$ & $\%$ & $\mathrm{~F}$ & $\%$ & $\mathrm{~F}$ & $\%$ & \\
\hline 1. Baik & 11 & 47,8 & 12 & 52,2 & 23 & 46,0 & \\
\hline 2.Kurang & 24 & 88,9 & 3 & 11,1 & 27 & 54,0 & 0,002 \\
\hline Total & 35 & 70,0 & 15 & 30,0 & 50 & 100 & \\
\hline
\end{tabular}

Berdasarkan tabel 3 diketahui (70\%) yang belum menerapkan perilaku kesehatan reproduksi sebagian besar adalah remaja jalanan yang sikapnya negatif yaitu sebanyak 24 responden $(88,9 \%)$.

Tabel 4 Hubungan Pengaruh Teman Sebaya dengan Perilaku Kesehatan Reproduksi di YPAB Batam

\begin{tabular}{lccccccc}
\hline \multirow{2}{*}{$\begin{array}{c}\text { Pengaruh } \\
\text { Teman Sebaya }\end{array}$} & \multicolumn{9}{c}{ Perilaku Kesehatan } & P Value \\
\cline { 2 - 7 } & $\begin{array}{c}\text { Tidak } \\
\text { Berperilaku }\end{array}$ & \multicolumn{2}{c}{ Berperilaku } & Total & \\
\cline { 2 - 8 } & $\mathrm{F}$ & $\%$ & $\mathrm{~F}$ & $\%$ & $\mathrm{~F}$ & $\%$ & \\
\hline 1. Pengaruh Baik & 5 & 31,3 & 11 & 68,8 & 16 & 32,0 & \\
\hline 2. Pengaruh Buruk & 30 & 88,2 & 4 & 11,8 & 34 & 68,0 & \\
\hline Total & 35 & 70 & 15 & 30,0 & 50 & 100 & \\
\hline
\end{tabular}

Berdasarkan tabel 4 diketahui $(70,0 \%)$ yang belum menerapkan perilaku kesehatan reproduksi sebagian besar adalah remaja jalanan yang memiliki pengaruh teman sebaya yang buruk yaitu sebanyak 30 responden $(88,2 \%)$ 
Tabel 5 Hubungan Akses Media Informasi dengan Perilaku Kesehatan Reproduksi di YPAB Batam

\begin{tabular}{lccccccc}
\hline \multirow{2}{*}{$\begin{array}{c}\text { Akses Media } \\
\text { Informasi }\end{array}$} & \multicolumn{9}{c}{ Perilaku Kesehatan } & P Value \\
\cline { 2 - 7 } & \multicolumn{2}{c}{$\begin{array}{c}\text { Tidak } \\
\text { Berperilaku }\end{array}$} & \multicolumn{2}{c}{ Berperilaku } & Total & \\
\cline { 2 - 7 } & $\mathrm{F}$ & $\%$ & $\mathrm{~F}$ & $\%$ & $\mathrm{~F}$ & $\%$ & \\
\hline 1. Pernah & 7 & 36,8 & 12 & 63,2 & 19 & 38,0 & \\
\hline 2. Tidak Pernah & 28 & 90,3 & 3 & 9,7 & 31 & 62,0 & 0,000 \\
\hline Total & 35 & 70 & 15 & 30,0 & 50 & 100 & \\
\hline
\end{tabular}

Berdasarkan tabel 5 diketahui $(70,0 \%)$ remaja jalanan yang belum menerapkan perilaku kesehatan reproduksi adalah yang tidak terpapar akses media informasi yaitu sebanyak 28 responden $(90,3 \%)$.

\section{Pembahasan}

Pengetahuan merupakan hasil dari tahu dan ini terjadi setelah orang melakukan penginderaan terhadap suatu objek tertentu. Pengetahuan adalah kesan di dalam pikiran manusia sebagai hasil penggunaan panca indera (Notoatmodjo, 2010). Hasil penelitian ini sejalan dengan hasil penelitian Ningsih Hasrum (2012) yang dilakukan di Yayasan Girlan Nusantara Sleman Kota Yogyakarta tentang "Hubungan Tingkat Pengetahuan Kesehatan Reproduksi dengan Perilaku Seksual Remaja Pada Anak Jalanan". Di dapati hasil yaitu $70 \%$ responden memiliki pengetahuan yang kurang.

Secara umum pengetahuan responden pada penelitian ini tentang kesehatan reproduksi adalah buruk, hal tersebut dapat terjadi karena adanya faktor lain yang mempengaruhi pengetahuan remaja jalanan antara lain tingkat pendidikan, informasi/media massa, social budaya dan ekonomi, lingkungan, dan motivasi (Notoatmodjo 2007). Hal tersebut sesuai dengan teori Kholik (2015), Pengetahuan seseorang dipengaruhi oleh faktor pendidikan. Pengetahuan sangat erat hubungannya dengan pendidikan, dimana dengan pendidikan yang tinggi maka orang tersebut diharapkan akan semakin luas pengetahuannya. Pendidikan diperlukan untuk mendapatkan informasi misalnya hal-hal yang menunjang kesehatan bukan sebaliknya sehingga dapat meningkatkan kualitas hidup, termasuk dalam hal ini informasi tentang kesehatan reproduksi. Dengan mendapatkan informasi yang benar tentang kesehatan reproduksi, akan dapat mencegah seseorang untuk tidak berperilaku kesehatan reproduksi itu sendiri, bahwa perilaku seseorang dapat dipengaruhi oleh beberapa faktor yang berasal dari dalam diri individu itu sendiri, diantaranya adalah persepsi dan proses belajar.

Berdasarkan uraian di atas, peneliti berasumsi bahwa pengetahuan adalah satu faktor yang dapat menentukan perilaku kesehatan reproduksi, tetapi pengetahuan tidak mutlak diperoleh dari pendidikan formal saja, akan tetapi dapat diperoleh dari pendidikan 
yang nonformal. Seseorang dengan tingkat pendidikan rendah tidak berarti mutlak berpengetahuan rendah pula dan seseorang dengan tingkat pendidikan tinggi berarti mutlak berpengetahuan baik pula.

Sebagian besar responden memiliki pengetahuan yang buruk, hal tersebut dapat terjadi dikarenakan kurangnya informasi ataupun penyuluhan tentang kesehatan reproduksi. Peningkatan pengetahuan tentang kesehatan reproduksi dapat dilakukan dengan cara penyuluhan dan sosialisai, semakin baik pengetahuan remaja jalanan tentang kesehatan reproduksi maka di harapkan semakin banyak juga remaja jalanan yang berperilaku kesehatan reproduksi. Seperti yang dituangkan di Notoatmodjo 2002 dalam Yuliana 2014 yaitu pengetahuan remaja jalanan merupakan hasil tahu dan ini terjadi setelah orang melakukan penginderaan terhadap suatu objek tertentu. Pengetahuan merupakan faktor yang penting untuk terbentuknya tindakan seseorang.

Hasil penelitian ini sejalan dengan hasil penelitian Diah Ismalastia (2016) yang dilakukan di Kota Klaten mengenai "Hubungan Pengetahuan Dan Sikap Dengan Perilaku Berisiko Seks Bebas Anak Jalanan Di Rumah Singgah Kota Klaten”. Di dapati hasil yaitu sebagian besar reponden yang memiliki sikap kurang baik yaitu sebesar 17 orang dengan berperilaku berisiko seks bebas sebesar 11 orang $(64,7 \%)$. Sikap adalah respon tertutup seseorang terhadap stimulus atau objek tertentu, yang sudah melibatkan faktor pendapat dan emosi yang bersangkutan (senang, tidak senang, setuju, tidak setuju, baik-tidak baik dan sebagainya). Sikap merupakan penguatan positif atau negatif terhadap objek yang bersifat psikologis. Sikap merupakan kecenderungan (tendency) untuk mendekati (approach) atau menjauhi (avoid) serta melakukan sesuatu, baik secara positif maupun negatif terhadap suatu lembaga, peristiwa, gagasan atau konsep (Azwar, 2010).

Hasil penelitian ini menunjukkan sikap responden terhadap kesehatan reproduksi bernilai negatif, selain di pengaruhi oleh rendahnya pengetahuan remaja jalanan, sikap mereka juga dipengaruhi oleh lingkungan. Banyak remaja jalanan yang cenderung bersikap negatif terhadap kesehatan reproduksi sehingga mempengaruhi pandangan remaja jalanan yang lain untuk bersikap negatif juga. Selain dipengaruhi pengalaman pribadi, sikap juga dipengaruhi oleh kebudayaan, orang lain yang dianggap penting, media massa, institusi atau lembaga tertentu serta faktor emosi dalam diri individu yang bersangkutan (Azwar, 2011).

Berdasarkan hasil wawancara yang telah dilakukan oleh peneliti terhadap remaja jalanan, alasan mereka tidak berperilaku kesehatan reproduksi adalah karena kurangnya pengetahuan dari kesehatan reproduksi itu sendiri dan juga dari lingkungan yang kebanyakan menghabiskan waktu bersama lawan jenis mereka sehingga mereka terlibat 
dalam aktivitas seksual dan faktor lain yang mendorong mereka tidak berperilaku kesehatan reproduksi adalah ajakan teman sebayanya seperti teman akrab, teman sekolah, teman yang dekat dari rumahnya. Meskipun awalnya kebanyakan remaja jalanan tidak ingin melakukan hal tersebut, namun karna adanya ajakan, bujukan atau paksaan dari teman sebayanya yang akhirnya membuat mereka tidak berperilaku kesehatan reproduksi.

Peneliti berasumsi bahwa pengaruh teman sebaya juga sebagai salah satu faktor yang dapat berpengaruh terhadap seseorang untuk berperilaku kesehatan reproduksi. Apabila berteman dengan yang sudah berperilaku kesehatan reproduksi maka kemungkinan besar terman sebaya berpengaruh dalam melaksanakan perilaku kesehatan reproduksi.

Hasil penelitian ini sejalan dengan hasil penelitian Dina Putri (2017) yang dilakukan di Yogyakarta tentang "Peran Teman Sebaya Dan Paparan Media Pornografi Terhadap Perilaku Seksual Remaja”. Di dapati hasil yaitu remaja dengan peran teman sebaya yang negatif memiliki peluang 1,34 kali lebih besar untuk melakukan perilaku seksual berisiko dibandingkan remaja dengan peran teman sebaya yang positif $(\mathrm{OR}=1,34 ; 95 \% \mathrm{CI}: 1,16-$ 1,56). Teman sebaya merupakan faktor penguat terhadap pembentukan perilaku remaja termasuk perilaku seksual pra nikah (Dewi, 2012). Morton dan Farhat (2010) dalam Dewi (2012) menyatakan bahwa teman sebaya mempunyai kontribusi sangat dominan dari aspek pengaruh dan percontohan (modelling) dalam berperilaku seksual remaja dengan pasangannya Menurut hasil penelitian pengaruh teman sebaya yang di maksud adalah pola pertemanan dan bentuk kesetia kawan atau solidarisas.

Hasil penelitian ini juga sejalan dengan hasil penelitian Utami Lubis (2017) yang dilakukan di Yogyakarta tentang "Peran Teman Sebaya Dan Paparan Media Pornografi Terhadap Perilaku Seksual Remaja Di Sekolah Tinggi Ilmu Kesehatan Yogyakarta”. Di dapati hasil yaitu hasil analisis bivariat menunjukkan bahwa terdapat hubungan yang bermakna $(\mathrm{p}<0,05)$ antara peran teman sebaya, paparan media pornografi, kontrol diri, alkohol dan narkoba terhadap perilaku seksual remaja. Hasil analisis regresi logistik ditemukan bahwa variabel yang paling dominan berhubungan dengan terjadinya perilaku seksual remaja adalah alkohol dan narkoba (OR: 3,110 $95 \% \mathrm{CI}=1,011-9,564)$.

Kemajuan teknologi yang terjadi pada saat ini telah membawa dampak perubahan bagi masyarakat, baik itu dampak yang positif maupun dampak negatif. Kemajuan teknologi menyebabkan komunikasi antar negara menjadi semakin mudah dan lancar, sehingga kebudayaan luar negeri lebih terasa pengaruhnya. Dampak yang paling terasa adalah pada tata budaya, moral, dan tata sosial masyarakat pada umumnya dan pada generasi muda khususnya. Salah satu masalah yang dihadapi remaja dan menjadi masalah bagi 
JURNAL SEHAT MASADA VOLUME XV

lingkungannya adalah aktivitas seksual yang akhir-akhir ini nampak menjurus pada hal-hal negative. Dikatakan negative karena para remaja bersikap dan bertingkah laku yang menyimpang, hal ini dapat dibuktikan dengan adanya berbagai macam perilaku seksual disalurkan dengan sesama jenis kelamin, dengan anak yang belum cukup umur, dan sebagainya. Sebagai media informasi, televisi memiliki kekuatan yang kuat (powerful) untuk menyampaikan pesan. Media ini dapat mengalirkan pengalaman yang seolah- olah dialami sendiri dengan jangkauan yang luas dalam waktu yang bersamaan. Penyampaian isi pesan seolah-olah langsung antara komunikator dan komunikan.

Menurut peneliti, dalam penelitian kali ini akses media informasi memiliki keterkaitan yang sangat erat dengan informasi. Remaja jalanan yang kurang mengetahui tentang perilaku kesehatan reproduksi lebih banyak belum pernah mendapatkan informasi yang seharusnya bisa mereka dapatkan melalu media informasi. Apalagi media informasi jaman sekarang sudah semakin canggih, tetapi karena remaja jalanan masih belum banyak mendapatkan informasi tentang perilaku kesehatan reproduksi melalu akses media informasi maka dari itu remaja jalanan masih banyak yang belum tau sehingga mereka masih banyak yang belum menerapkan perilaku kesehatan reproduksi itu sendiri.

\section{KESIMPULAN}

Hasil penelitian ini menggambarkan bahwa pengetahuan, sikap, pengaruh teman sebaya serta akses media informasi merupakan faktor yang mempengaruhi perilaku kesehatan reproduksi pada remaja. Dinamika remaja pada penelitian ini sebagian besar menunjukkan mempunyai pengetahuan yang kurang, sikap yang negatif, pengaruh teman sebaya yang buruk serta tidak pernah mendapatkan akses media informasi, oleh sebab itu perilaku kesehattan reproduksi yang dimiliki oleh remaja terseut cenderung kurang baik.

Hasil penelitian ini juga dapat disimpulkan bahwa hipotesis penelitian diterima yang berarti menyatakan terdapat hubungan yang signifikan antara faktorfaktor yang mempengaruhi perilaku kesehatan reproduksi yaitu pengetahuan dengan nilai signifikansi $0,000(\mathrm{p}<0.05)$, sikap dengan nilai signifikansi 0,002 ( $\mathrm{p}<0.05)$, pengaruh teman sebaya dengan nilai signifikansi $0,000(\mathrm{p}<0.05)$ serta akses media informasi dengan nilai signifikansi $0,000(\mathrm{p}<0.05)$. Hal ini menunjukkan bahwa semakin baik sikap remaja, pengaruh teman sebaya serta media informasi yang didapatkan oleh seorang remaja, maka akan semakin baik pula perilaku kesehatan reproduksinya. 


\section{DAFTAR PUSTAKA}

1. Apit, S. S. (2013). Jurnal Kesehatan Masyarakat, 9(1), 30-36.

2. Arum, Yasnani, A. (2016). Hubungan Pengetahuan, Akses Media Informasi Dan Peran Keluarga Terhadap Perilaku Seksual Pada Siswa Smk Negeri 1 Kendari Tahun 2016, 1-11.

3. Ayuningtias, B. (2016). Gambaran Perilaku Seksual Anak Jalanan Di Kota Semarang.

4. Budiman. (2013). Pengetahuan, Sikap Dan Perilaku Mengenai Kesehatan Reproduksi Siswa Sma Swasta Dan Madrasyah Alliyah.

5. Diah, N. (2016). Hubungan Pengetahuan Dan Sikap Dengan Perilaku Beresiko Seks Bebas Anak Jalanan Di Rumah Singgah Kota Klaten.

6. Dinsos (2019). Data Anak Jalanan Kota Batam Tahun 2019. Batam: Dinas Sosial

7. Hutami, G. (2014). Pada Anak Jalanan Di Semarang, 1-22.

8. Ibrahim, I. A., \& Sulaiman, Y. (2016). Al - Sihah: Public Health Science Journal Gambaran Pengguna Narkoba Inhalasi ( Ngelem ) Pada Anak Jalanan Di Kota Makassar Tahun 2015, 8.

9. Karyati, S. (2017). Lingkungan Sosial, Teman Sebaya, Spiritualitas Dan Perilaku Seksual Pranikah Remaja Anak Jalanan, (February), 1418-1425.

10. Lizam, T. C., Prabandari, Y. S., \& Kumara, A. (2009). Dan Kecenderungan Untuk Berhenti Merokok Melalui Improving Positive Attitude Toward Non Smoking Behavior, 25(2), 74-81.

11. Lubis, D. (2017). Pendahuluan Saat Ini Kesehatan Reproduksi Masih Merupakan
Masalah Kesehatan Masyarakat Yang Cukup Besar Skalanya Di Indonesia . Hal Ini Dapat Dilihat Dari Data Dan Fakta Pada Beberapa Komponen Kesehatan Reproduksi , Salah Satunya Adalah Masalah Kesehatan, 47-54.

12. Notoatmodjo, S. (2015). Metode Penelitian Kesehatan. Jakarta: Pt. Rineka Cipta.

13. Ningsih, H. (2012). Hubungan Tingkat Pengetahuan Kesehatan Reproduksi Dengan Perilaku Seksual Remaja Pada Anak Jalanan Di Yayasan Girlan Nusantara Sleman Yogyakarta 2012.

14. Nursal, D. (2018). Perilaku Seksual Murid Smu Negeri Di Kota Padang Tahun 2007, (March 2008). Https://Doi.Org/10.24893/Jkma.2.2.175180.2008

15. Puspitaningsih, R. (2015). Hubungan Antara Tingkat Pengetahuan Reproduksi Dengan Perilaku Seksual Anak Jalanan Di Alun-Alun Klaten Jawa Tengah.

16. Riyatno, A. (2019). Hubungan Tingkat Pengetahuan Kesehatan Reproduksi Dengan Perilaku Anak Jalanan Yang Telah Melakukan Seks Bebas Di Kota Yogyakarta.

17. Santina, M. (2011). Diajukan Sebagai Salah Satu Syarat Untuk Memperoleh Gelar Sarjana Kesehatan Masyarakat Meinil Santina 0906616496.

18. Yanti, E. (2016). Pengetahuan Kesehatan Reproduksi Remaja Pada Siswa Siswi Kelas X-Xi Sma Pada Siswa Siswi Kelas $X-X i$ Sma.

19. Yaunin, Y., \& Lestari, Y. (2016). Artikel Penelitian Faktor-Faktor Yang Berhubungan Dengan Perilaku Seksual Remaja Di Kota Padang, 5(2), 448-455. 